\title{
PSYCHE.
}

\section{AN UNUSUAL APPEARANCE OF SCHISTOCERCA AMERICANA.}

By W. S. BLATCHLEy, TERRE HAUTE, IND.

About three o'clock in the morning of April I Ith, I893, the city of Terre Haute, Indiana, was visited with a severe storm of rain and wind from the southwest.

A number of buildings were unroofed and many shade and forest trees twisted and broken off.

While on my way to the High School building several persons informed me that they had that morning seen specimens of "gigantic grasshoppers" on the streets but were unable to capture them. About ten o'clock one of my former pupils brought me two living, mature specimens of that large and handsome locust, Schistocerca americana Drury, which she had picked up from the sidewalk near her home. I was much surprised to see them as the earliest date at which I had before noted the species in this vicinity was June 27, I 89 , when I found them common and freshly moulted in a small prairie east of Terre Haute. I have never seen the young or imagos in winter but have taken the latter in numbers as late as November 22nd.
On looking up all references as to their time of appearance in other localities I find nothing definite as to whether the species hibernates as imago or young and but little about its appearance in spring. Dr. Riley gives June I $4^{\text {th }}$ as the date of its appearance at St. Louis, ${ }^{*}$ and states $\dagger$ that the average period between hatching and maturity is 70 days. He also statesł that "Certain large locusts, belonging to the genera Acridium and Oedipoda, hibernate in the full grown, winged state ... and that two species which are most often found with the young (of Melanoplus spretus Uhler) are the American Acridium, (Acridium americanum Drury) and the Coralwinged Locust ( Oedipoda phoenicoptera Germ)." He does not say in so many words that americana hibernates in the mature state, though from the context one would infer that he so meant. In this locality the Coralwinged Locust, now known as Hippis-

* First Report U. S. entomological commission, 22I.

† Loc. cit. 237.

$\ddagger$ Loc. cit. 236 . 
cus tuberculatus Beauv., hibernates as a larva and reaches maturity about May ist.

Dr. Cyrus H. Thomas in $187 \mathrm{r}$ described* a form of $S$. americana under the name of Acridium ambiguum and stated that in southern Illinois it always appears in small numbers in April or May while americana never appears earlier than the middle of July. In another place $\dagger$ he says of ambiguum: "It is this variety which appears occasionally to pass the winter in the perfect state." The specimens in my possession may be his var. ambiguum but as far as I can see they do not differ either in structure or color from specimens of the typical americana taken in this vicinity in October.

McNeill says of $S$. americana, that its earliest recorded appearance at Rock Island, Illinois, is Sept. 2oth $\ddagger$; while Scudder records its capture at Fort Reed and Jacksonville,Florida, on April roth.§ This comprises all the infor- mation at hand as to dates of appearance at other places.

That the species is, to a certain extent, migratory is well known, numerous instances of this habit having been recorded by Riley,* Thomas, and other writers; but these migrations all occurred in late summer or in autumn.

Its unexpected appearance here so early in the season gives rise in my mind to the following questions: Where, if at any place, in the United States does it hibernate as imago? Is it double or treble brooded in such a locality? At what point southwest of Terre Haute, Indiana, does it occur mature as early as April I 2th in sufficient abundance that it could be blown in numbers and scattered over the streets of this city? In this locality it is evidently double brooded, the first brood maturing in June or July from eggs hatched in spring, the other maturing in September or October.

\section{HOSTS OF NORTH AMERICAN TACHINIDAE, ETC., I.}

BY C. H. TYLER TOWNSEND, LAS CRUCES, N. MEX.

The following twenty-seven species of tachinids, sarcophagids, etc., were all bred by Prof. S. A. Forbes, in Illinois. They were included in a large collection of Muscidae sent to me for determination from the Illinois State

* U. S. geol. surv. of Montana, 1871, 447 .

† Psyche, VI, 73.

$\ddagger$ Ninth Rep. st. ent Ill., I880, 133 .

§ Proc. Bost. soc. nat. hist., XIX, 86.
Laboratory of Natural History at Champaign.

r. Cistogaster immaculata Mcq.One bred from Leucania unipuncta.

2. Ocyptera euchenor Wlk. - One bred from "Acrididae." Also one (smaller specimen) from Leucania unipuncta.

* First Rep. U. S. ent. comm., 449. 

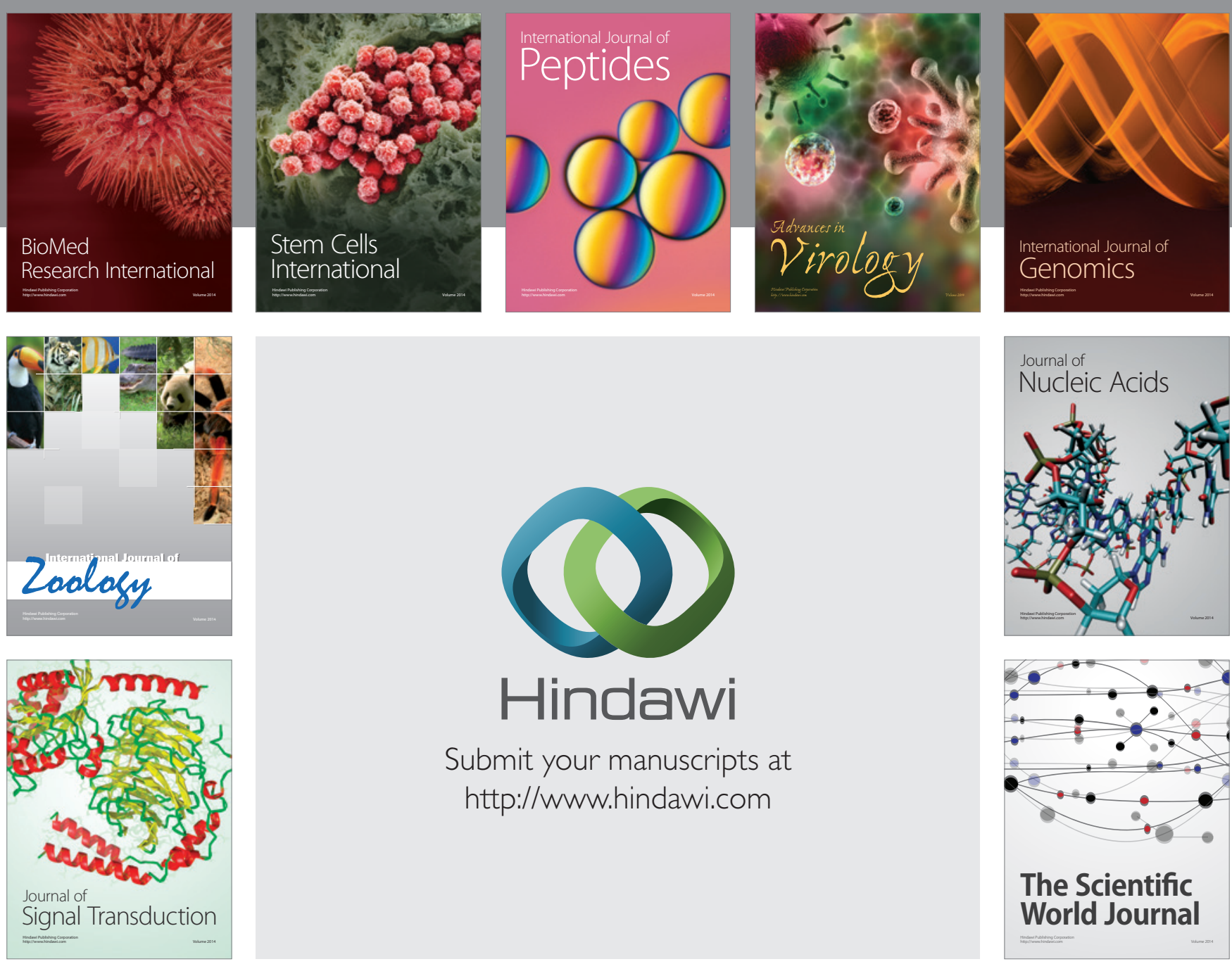

Submit your manuscripts at

http://www.hindawi.com
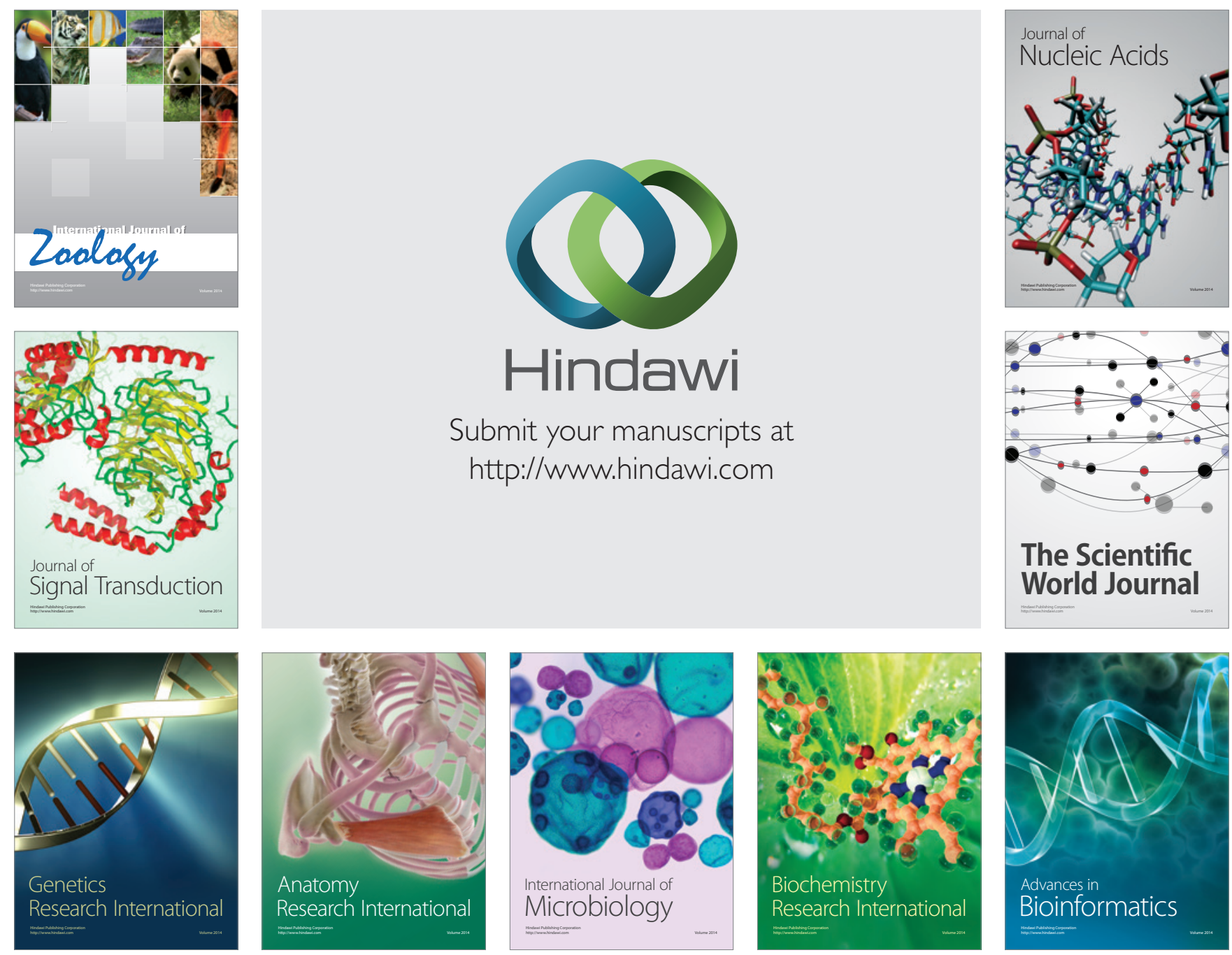

The Scientific World Journal
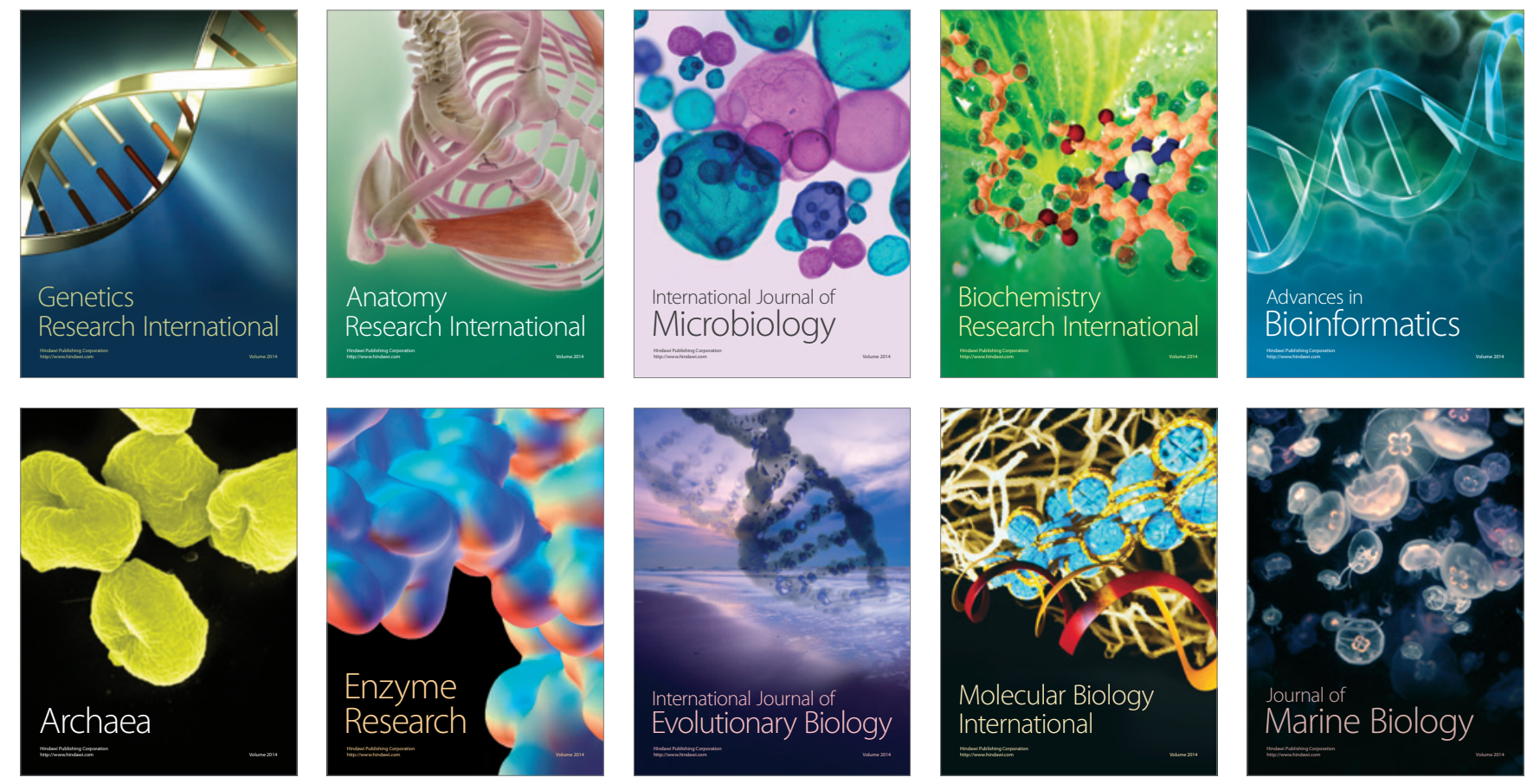